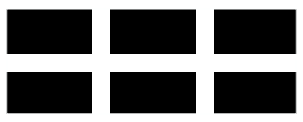

The WiLliam DAVIDSON Institute AT THE UNIVERSITY OF MICHIGAN BUSINESS SCHOOL

Re-employment Probabilities and Wage Offer Function for Russian Labor Market

\author{
By: Natalia V. Smirnova
}

William Davidson Working Paper Number 547

July 2003 


\title{
Re-employment Probabilities and Wage Offer Function for Russian Labor Market
}

\author{
Natalia V. Smirnova \\ University of Connecticut, $U S A^{1}$
}

\begin{abstract}
This paper addresses labor market transformation in Russia. It elaborates on the theory of job search and focuses on the following issues: (1) evaluation of the reemployment probabilities (hazard rates) for the Russian unemployed; and (2) estimation of the wage offer distribution for the transforming labor market.

We use data from Phase II of the Russia Longitudinal Monitoring Survey (RLMS) to estimate the employment and wage offer functions for Russian workers who found a job after having been unemployed. The socio-economic factors that are evaluated for their effect on re-employment probabilities as well as wage offers are sex, education level, work experience, sector of employment (public and private), number of children and number of elderly in the household. In addition the effectiveness of search methods and search intensity are considered as factors influencing the employment and wage offer functions.

The results show that the best prospects for re-employment in Russia in 19942000 are for a college graduate male with fewer years of experience who used many different strategies when looking for a job. Private sector employment has the most powerful upward effect on the wage offer curve, followed by college education level. Public sector employment, being a female, number of years of experience, number of children, and number of elderly in the household, all have a negative affect on the wage offer distribution.
\end{abstract}

JEL Code: J64, P23

Keywords: Russia, transition, labor market, wage offer curve

\footnotetext{
1 Address: Department of Economics, University of Connecticut, Storrs, CT, 06269, USA. Natalia.Smirnova@Uconn.edu
} 


\section{RE-EMPLOYMENT PROBABILITIES AND WAGE OFFER FUNCTION FOR RUSSIAN LABOR MARKET}

\section{Non-Technical Summary}

This research addresses labor market transformation in Russia. It elaborates on the theory of job search and focuses on the following issues: (1) evaluation of the reemployment probabilities (hazard rates) for different socio-economic groups; and (2) estimation of wage offer distribution for the transforming labor market. We use data from Phase II of the Russia Longitudinal Monitoring Survey (RLMS) to estimate the employment and wage offer functions for Russian workers who found a job after having been unemployed. We take into account the effectiveness of search strategies used and correct for truncation in wage offers.

In this paper we draw specifically upon Kieffer and Neumann's (1979) evaluation of wages, Narendranathan and Nickell's (1986) estimation of parameters in a job search model, Holzer's (1988) analysis of the search method choice, and Hill's (1982) sample selection bias correction application.

The binomial logit-OLS estimation method with sample selection bias correction on pooled data from Rounds 5-9 of RLMS is used. First, we estimate the employment function by logit, which models the probability of gaining employment after being unemployed. The factors considered are sex, education, experience, sector of employment and search methods' success rate, which are hypothesized to capture the main determinants of job search behavior. The results show that individual characteristics, as well as the search method used, play a decisive role in the reemployment prospects of the unemployed.

Search effectiveness, or the probability of success in finding a job after using a particular search strategy, has a very powerful effect on the employment probability. This might be indicative of the fact that search strategies and their success rate are an important component of the labor market adjustment in Russia. The improvement of employment related programs and their success rate in placing people in jobs, development of new search methods (Internet search, for example), and increasing of the 
information data base in Russia would play an important role in decreasing the duration and level of unemployment.

Secondly, we estimate the wage offer function by OLS. Two versions are considered: standard and corrected for selectivity bias. The correction is made by using inverse Mills ratio applicable to binomial logit specification. Two versions of the wage equation give consistent results.

Private sector employment has the most powerful upward effect on the wage offer curve, followed by college education level. Private sector employment level, sex and years of experience affect the wage offer function downwards. We conclude that the development of policies promoting the growth of private sector, as well as policies protecting women in the workplace and during the hiring process would increase the general level of wages faced by Russian unemployed and help build a stable environment in the Russian labor market.

In conclusion, the paper is the first attempt to apply the theoretical job search models to the Russian labor market. The results are consistent with earlier estimations for other countries, however, the unique data characteristics has to be kept in mind while making generalizations about the behavior of unemployed in transforming Russia. 


\section{Natalia V. Smirnova}

\section{Re-employment Probabilities and Wage Offer Function for Russian Labor Market}

\section{Introduction}

This paper addresses labor market transformation in Russia. It elaborates on the theory of job search and focuses on the following issues: (1) evaluation of the reemployment probabilities (hazard rates) for the Russian unemployed; and (2) estimation of the wage offer distribution for the transforming labor market. Though theoretical and empirical work on job search has attracted considerable attention in the 1980s, none has been done along these lines for the transforming economies of Central and Eastern Europe (CEE) in general, and Russia in particular. The work in this context is potentially useful not only for better understanding of unemployment but for designing diverse labor market programs and measuring their effects.

The literature on job search in the labor market has advanced substantially in the past two decades. Mortensen (1999) gives an overview of new developments in models of search. Nevertheless, in this paper we draw specifically upon Kieffer and Neumann's (1979) evaluation of wages, Narendranathan and Nickell's (1986) estimation of parameters in a job search model, Holzer's (1988) analysis of search intensity, and Hill's (1982) sample selection bias correction application. These are original simple models that are useful in the initial estimation of the parameters of wage and employment equations for the labor market that was not yet intensely analyzed.

We use data from Phase II of the Russia Longitudinal Monitoring Survey (RLMS) to estimate the employment and wage offer functions for Russian workers who found a job after having been unemployed. The socio-economic factors that are evaluated for their effect on re-employment probabilities as well as wage offers are sex, education level, work experience, sector of employment (public and private), number of children and number of elderly in the household. In addition the effectiveness of search methods and search intensity are considered as factors influencing the employment and wage offer functions.

The paper is organized as follows: Section 2 offers a description of the data; Section 3 identifies the theoretical model; Section 4 describes the statistical model; Section 5 
provides the description of the estimation procedure; Section 6 discusses empirical results; Section 7 presents the conclusions.

\section{Data}

We use data from the Russian Longitudinal Monitoring Survey (RLMS) conducted by the Carolina Population Center at the University of North Carolina at Chapel Hill. ${ }^{2}$ The RLMS is the result of an ongoing effort of U.S. and Russian scientists and officials to measure the impact of market reforms on the living and health conditions of the Russian population. It provides information about migration, work, medical services, use of time, and health evaluation of men, women and children in Russia since the beginning of the economic transformation in 1991.

According to the authors of the survey, the RLMS is the first nationally representative random sample for Russia. It supports both efficient cross-sectional and aggregate longitudinal analyses of change in the Russian household population. The survey is designed as a repeated sample of each household dwelling. Thus, instead of following individuals or households from one year to the next, RLMS merely returns to the same dwelling sampled in the previous year. Consequently, by definition, all households who move locally or migrate to another region are automatically lost to follow-up. If the previous occupants of a sample dwelling had moved, the new occupants are invited to join the survey sample.

The data have been collected in two phases. The first phase consists of four rounds (1-4) between May 1992 and July 1994, while the second phase covers another six rounds (5-10), and is dated between October 1994 and April 2002. We use the information from Phase II (Rounds 5-9), since it reflects a revised questionnaire, and is more refined and consistent throughout the rounds. Furthermore, the sampling methods (multi-stage probability sampling) and the conduct of the survey in the second phase proved far superior to those used in the first round. ${ }^{3}$

The rounds of the RLMS correspond to the following calendar years: Round 5 1994, Round 6 - 1995, Round 7 - 1996, Round 8 - 1998, Round 9 - 2000. The analysis

\footnotetext{
${ }^{2}$ The project description at $\underline{w w w . c p c . u n c . e d u / r l m s}$ provides complete information about the RLMS survey and its sampling procedure.

${ }^{3}$ Clarke (1999), p.288.
} 
is performed on pooled data for the following reasons: (a) the initial analysis of the sample reveal no significant differences in the behavior of variables through the rounds ${ }^{4}$; and (b) when dummy variables for each round were introduced to the pooled data set, their estimates were statistically insignificant ${ }^{5}$.

RLMS conducts three types of questionnaires: individual, household and community. The research agenda for this project compels us to use the individual questionnaire.

The individual questionnaires of Rounds 5, 6, 7, 8 and 9 contain a question: "Are you working?" The choices of answers are: (1) yes (working) ${ }^{6}$; (2) maternity leave or leave for taking care of a child under three years old; (3) any other paid leave; (4) unpaid leave; (5) no (not working). If a person answers that he is not working, he is asked if he would like to find work. The answer to the question: ["Did you go anywhere or see anyone looking for a job in the last 30 days?'] places an individual into the employment/unemployment category.

Individual questionnaires impose six choices of job search strategies on those who were not working at the time of the survey and looked for a job in the last 30 days: (1) applying to state employment agencies or labor registry offices; (2) applying to nongovernmental employment services; (3) contacting friends and acquaintances; (4) contacting relatives; (5) applying directly to an enterprise; (6) applying through advertising notices. Due to the small frequencies of responses for such categories as private employment agencies, relatives, and directly-to-enterprises and through the advertisements, we regrouped the categories into broader classes and added a "Multiple Job Search" strategy and "No Search" strategy, as follows:

1. Applying to state and private employment agencies (hereafter, AGENCIES).

4 Full descriptive analysis of the sample through the rounds of the RLMS benefited from the discussion of the following papers at the conferences:

- $\quad$ Job Search Effectiveness in Transitional Russia: Descriptive Analysis. Presentation at the European Association of Labour Economists (EALE) 2002 Annual Conference, La Sorbonne, Université Paris I, Paris, France, September 21.

- $\quad$ The Demographics of Russian Unemployed and Their Job Search Strategies. European Association of Labor Economists (EALE) 2001 Annual Conference, Juvaskyla, Finland, September 13.

- $\quad$ Who Are Russian Unemployed and What Are Their Job Search Strategies? Eastern Economic Association 2001 Annual Meeting, New York, February 24.

${ }^{5}$ t-test revealed that estimates of the rounds' dummies were statistically insignificant at $5 \%$ level.

6 The RLMS considers "the concept of work as applying not only to those who are involved in production, but also for those not working in an enterprise but who are engaged in independent work or are selfemployed." (RLMS: Special instructions to interviewers regarding this question.) 
2. Working through friends, acquaintances and relatives (CONTACTS).

3. Contacting firms directly and in response to advertisements (FIRMS).

4. Using more than one single search strategy (MULTIPLE).

5. No search at all (NOT APPLIED).

It appears that the addition of MULTIPLE to the set of strategies would violate the necessary condition of mutual exclusiveness. However, the respondents are carefully separated based upon their answer to the question "Where did you search for a job?" If they checked more than one source, they are assumed to have used multiple job search strategy. Therefore, for analytical purposes the above mentioned set of strategies consists of mutually exclusive elements.

The NOT APPLIED strategy was added due to the fact that a substantial number of people in the sample answered the question about engagement in job search negatively (they did not apply anywhere for a job), but were employed in the subsequent round. By allowing for NOT APPLIED strategy, we recognize that people who do not search still have a chance of obtaining a job in the next period. As Mortensen (1986) points out, "a casual conversation ... over a beer is a surprisingly common method of finding a job." ${ }^{77}$ Furthermore, Clarke (1999) identified the "Did not Look, But Found a Job" method through the open response question in a work history survey. ${ }^{8}$ This method, according to Clarke (1999), includes such categories as "by distribution", "worked there before", "they invited me", and "practical training placement". 9

Figure 1 plots the use of the broad categories series over time for those who was not working and searched for a job. The use of AGENCIES increased between Rounds 5 and 6 , but then fell off dramatically. The popularity of FIRMS decreased between Rounds 5 and 8, but then rose in Round 9. The use of CONTACTS and MULTIPLE strategies steadily increased through the rounds.

The socio-economic characteristics of the sample - sex and education structure, experience levels, sector of employment, number of children and number of elderly in the household statistics - as well as the search strategies' use for pooled data are presented in Appendix 1.

\footnotetext{
${ }^{7}$ Mortensen (1986), p.854.

${ }^{8}$ Clarke (1999), p. 205.

${ }^{9}$ Ibid.
} 


\section{Economic Model}

Job search theory is essentially concerned with the optimal behavior of an unemployed individual who is engaged in a random search for a suitable job using a particular set of the job search strategies. The individual's optimal strategy is to follow a reservation wage policy -- that is, to accept a job if the associated wage $w$ exceeds the optimal reservation wage, $\xi$, and otherwise continue searching. Reservation wages are not, however, directly observable; this makes it difficult to test the implications of the theory directly: one cannot proceed directly to estimate the determinants of $\xi$. An alternative is to analyze the observed employment and earnings patterns across individuals. If two otherwise identical individuals differ in their search effectiveness, then their expected probability of finding a job in any number of periods will differ as will their expected earnings upon re-employment, and these will both differ in a systematic way. In this paper we follow the model of Kiefer and Neumann (1979), who use the information on post-unemployment wages of those people who left unemployment within a certain time period to estimate the re-employment probabilities and the wage offer function.

As time passes, new vacancies come to an individual's notice through the job search channels: contacts, advertisements, employment agencies, etc. Let $w$ be the wage associated with each new vacancy and this is assumed to be a random drawing from a known density $f(w)$. Let $q_{1}\left(z_{1}\right)$ be the probability per period that a vacancy comes to an individual's notice. Here $\mathrm{z}_{1}$ is a set of personal characteristics, which include individual and household characteristics, search effectiveness and search intensity.

Search effectiveness in our case is the success rate of obtaining a job after being unemployed and using a particular job search strategy. Search intensity in our case is the number of search methods used to look for a job ${ }^{10}$.

Let $q_{2}\left(z_{2}\right)$ be the known objective probability that the individual would actually be offered the job associated with the vacancy were s/he to make her/himself available. This, for example, would depend on variables $\left(z_{2}\right)$ that would affect his desirability as an employee. Thus, $q_{1} q_{2} f(w) d w$ can be thought of as the 'probability' of being offered a job

\footnotetext{
${ }^{10}$ We follow Holzer (1988), who justified utilizing number of methods used rather than time spent in defining search intensity.
} 
with a wage $w$ in any period. The time period is assumed to be small enough to ensure that there is a zero probability of being offered two or more jobs within that interval. If $q(z)=q_{1}\left(z_{1}\right) \cdot q_{2}\left(z_{2}\right)$, then the conditional probability of leaving the unemployment spell (i.e. the hazard function) is

$$
h=q(z) \int_{\xi}^{\infty} f(w) d w .
$$

In the literature one can find two approaches to estimating the hazard functions: reduced form and structural form. If all one is concerned with is the impact of key exogenous variables, such as unemployment benefits on the duration of unemployment or on re-employment probabilities, then one could use the reduced form approach. Search theory is then used as a framework for the interpretation of the results. This approach is essentially concerned with the formulation and estimation of the hazard function directly, making use of the information on the duration of the unemployment spell.

The structural form approach typically involves the imposition of the structure of the search theory at varying degrees on the data. The research under this category falls mainly into two types. One uses the maximum likelihood method to estimate the parameters of interest, and the other uses sample averages to calculate (rather than estimate) the elasticities of interest.

Given the knowledge we possess about the data availability, we use the structural form approach of the first type, following Kiefer and Neumann (1979), who estimate the wage offer distribution based on post-unemployment wage information. In addition, using their employment function, we are able to estimate the re-employment probabilities, which are the hazard rates, without the data on the duration of the unemployment spell. The specifics on the statistical model and estimation procedure are outlined in the sections that follow.

\section{Statistical Model}

Let the wage offer distribution facing the $i$ th individual be:

$$
\begin{aligned}
& \ln \left(w_{i}{ }^{0}\right)=x_{i}{ }^{\prime} \beta+\varepsilon_{i}{ }^{0} \\
& \text { with } \quad \varepsilon_{i} \sim N\left(0, \sigma_{0}{ }^{2}\right),
\end{aligned}
$$


and $x_{i}{ }^{\prime}=f\left(X_{i}, H_{i t}, Z_{i e t}, Q_{i j(t+1)}\right)$ containing characteristics of the worker and the labor market which affect the job search process: $X_{\mathrm{it}}$ is a vector of individual characteristics (including sex, education, experience and search intensity ${ }^{11}$ ) and subscript $i$ defines the individual; $H_{i t}$ is a vector of the characteristics of the individual's household (including the number of children and the number of elderly); $Z_{i e t}$ is a vector of characteristics of employment, obtained by an individual through a particular job search method (i.e. sector of employment (public or private)) and subscript $e$ defines the employment outcomes; and $Q_{i j(t+1)}$ is a vector of search effectiveness measured as probability of obtaining a job after being unemployed conditional on the search method used.

The reservation wage of the $i$ th individual is generated by:

$$
\begin{aligned}
& \ln \left(\xi_{i}\right)=Y_{i}^{\prime} \gamma+\varepsilon_{i}^{r} \\
& \text { with } \varepsilon_{i}^{r} \sim N\left(0, \sigma_{r}{ }^{2}\right) .
\end{aligned}
$$

The independent variable is $Y_{i}=f\left(X_{i}, H_{i t}\right)$, which includes a vector of individual characteristics $X_{i t}$, and a vector of household characteristics $H_{i t}$, as described above. An error term $\varepsilon_{i}^{r}$ represents inter-individual variation in the reservation wage, $\xi_{i}$, which is not captured by $Y_{i}$. We further assume that the two error terms are jointly distributed as bivariate normal with covariance $\sigma_{0, r}$.

An individual accepts a job if and only if $S_{i}=\ln \left(w_{i}^{0}\right)-\ln \left(\xi_{i}\right)$ is greater than zero. From (1) and (2) this condition is described by

$$
\begin{aligned}
& S_{i}=x_{i}^{\prime} \beta-Y_{i}^{\prime} \gamma+\varepsilon_{i}^{0}-\varepsilon_{i}^{r}=x_{i}^{\prime} \beta-Y_{i}^{\prime} \gamma+\varepsilon_{i}>0 \\
& \text { with } \varepsilon_{i} \sim N\left(0, \sigma_{0}^{2}-2 \sigma_{0, r}+\sigma_{r}^{2}\right) .
\end{aligned}
$$

Since the condition for observing an individual's wage is that (3) holds, it is clear that the distribution of observed wages is truncated - offers below $\xi_{\mathrm{i}}$ are not accepted and, therefore, not observed. We correct for selectivity bias by using the inverse Mill's ratio method.

\footnotetext{
${ }^{11}$ In earlier analysis we considered residence (i.e. geographical regions) as a factor influencing the job search behavior and outcome. However, surprisingly, geographical regions of residence did not show any significant effect on probability of re-employment, and were not different across individuals and across rounds. Thus, in this specification we omit this variable.
} 
If $\mathrm{w}_{\mathrm{i}}{ }^{0^{*}}$ is the logarithm of a drawing from the observed wage offers, then it is distributed with:

$$
\begin{aligned}
& E\left(w_{i}^{0^{*}}\right)=x_{i}^{\prime} \beta+\rho \sigma_{0} \lambda_{i} \\
& \operatorname{Var}\left(w_{i}^{0^{*}}\right)=\sigma_{\varepsilon}^{2}\left(1+\rho^{2} r_{i} \lambda_{i}-\rho^{2} \lambda_{i}^{2}\right), \\
& \text { where: }
\end{aligned}
$$

(a) $\quad \lambda_{i}=\phi\left(-r_{i}\right) /\left(1-\Phi\left(-r_{i}\right)\right)$,

(b) $\quad r_{i}=\left(x_{i}^{\prime} \beta-Y_{i}^{\prime} \gamma\right) / \sigma$,

(c) $\rho=\left(\sigma_{0}^{2}-\sigma_{0, r}\right) / \sigma_{0} \sigma$,

(d) $\quad \sigma=\left(\sigma_{0}^{2}-2 \sigma_{0, r}+\sigma_{r}^{2}\right)^{1 / 2}$.

Here $\phi$ and $\Phi$ are the standard normal density and distribution functions respectively, and $\lambda_{\mathrm{i}}$ is an inverse Mill's ratio. If $\lambda_{\mathrm{i}}$ were known, the regression:

$$
w_{i}^{0^{*}}=x_{i}^{\prime} \beta+\rho \sigma_{0} \lambda_{i}+\varepsilon_{i}
$$

could be estimated and $\beta$ and $\rho \sigma_{0}$ calculated. Heckman (1979) shows that the probit estimates of the normalized version of (3), that is,

$$
S_{i}^{*}=S_{i} / \sigma=\left(x_{i}^{\prime} \beta-Y_{i}^{\prime} \gamma\right) / \sigma+\varepsilon_{i} / \sigma=x_{i}^{\prime} \beta^{*}-Z_{i}^{\prime} \gamma^{*}+\varepsilon_{i}^{*},
$$

can be used to estimate $\lambda_{\mathrm{i}}$ consistently, which in turn provides consistent estimates of $\beta$ and $\rho \sigma_{0}$. We employ the work by Joel Hay (1980) who extends Heckman's (1979) "Mill's ratio" correction for probit choice models so that it is applicable to multinomial logit choice models. Note that the probit probabilities obtained from (8) (logit probabilities in our case) are the re-employment probabilities, which are the hazard rates of equation (5).

Collecting the equations with observable or partially observable dependent variables, we have the setup of our statistical model:

$$
\begin{array}{ll}
w_{i}^{0^{*}}=x_{i}^{\prime} \beta+\varepsilon_{i} & \text { (wage offer function) } \\
S_{i}^{*}=x_{i}^{\prime} \beta^{*}-Z_{i}^{\prime} \gamma^{*}+\varepsilon_{i}^{*} & \text { (employment function) }
\end{array}
$$

where the sign of $\mathrm{S}_{\mathrm{i}}{ }^{*}$ is observed and $\mathrm{w}_{\mathrm{i}}{ }^{0^{*}}$ is observed if $\mathrm{S}_{\mathrm{i}}{ }^{*}$ is positive. In the following section we provide the description of the estimation procedure. 


\section{Estimation Procedure}

In order to estimate the parameters of our model, we first estimate (10) by logit, then use the estimated logit probabilities to calculate a series on $\lambda$, the adjustment for the truncation in the observed wage offers. Then, conditional on the series for $\lambda(6)$, we estimate (9) by OLS.

In the employment equation (10), the dependent variable takes the value 1 if the unemployed individual in round $t$ has become employed in round $(t+1)$ and zero otherwise. There are two steps in estimation of the employment function (10). First, the vector of predicted probabilities of re-employment conditional on the search strategy used $\left(Q_{i j(t+1)}\right)$ is estimated. The search effectiveness vector estimation methodology is presented in Appendix 4. Second, this vector is used as one of the explanatory variables in the employment function. The significance of the overall fit is measured by a chisquared test against the binomial model. The coefficient estimates obtained are "reduced form" coefficients; that is, they represent the net effect of a factor on the probability of re-employment. At this stage we analyze the effect of socio-demographic factors on the hazard rates for the Russian labor market. Next we use these reduced form estimates in order to correct the wage predictions for potential sample selection bias. The correction procedure methodology is presented in Appendix 2.

The wage equation (9) is estimated by ordinary least squares (OLS) over the sample of individuals who were employed in the $(t+1)$ round of the survey after being unemployed in the previous round $(t)$, and a series on $\lambda(\mathrm{A} 2.1)$ that was entered as a regressor. The dependent variable is the logarithm of nominal monthly wages. The monthly wages in Rounds 5 and 6 are adjusted to take into account the ruble devaluation of $1998 .^{12}$

\section{Results}

As one can see from the discussion above the analysis can be broken down into two parts. First, we estimate the employment function (10) and assess the effects of sex,

\footnotetext{
${ }^{12}$ In August 1998 the Central Bank of Russian Federation defaulted on all its obligations. The devaluation
} of the ruble took place, where 1 ruble after August 1998=1000 rubles before August 1998 . 
education, experience, number of children, number of elderly, search effectiveness and search intensity on the probabilities of re-employment. Second, we estimate the wage offer function (9) corrected for truncation in the data and assess the effect of the same socio-economic variables plus the sector of employment on the wage offer distribution. Variable definitions, means and standard deviations are presented in Appendix 3.

\subsection{Employment Function for Russian Labor Market}

Employment function (10) contains a vector of search effectiveness $\left(Q_{i j(t+1)}\right)$, measured as probability of obtaining a job after being unemployed conditional on the search method used. The estimates of success probabilities of job search strategies are presented in Appendix 4. The most effective strategy, as would be expected, is MULTIPLE with predicted success probability of $42 \%$. The most effective single strategy is predicted to be CONTACTS with probability of $32 \%$. The strategy FIRMS occupies second place with $29 \%$. The AGENCY is the least successful with $26 \%$. The NOT APPLIED strategy surprisingly has a quite high $20 \%$ success rate, which proves our earlier proposition that people who do not use any conventional search channels still gain employment.

The results of the employment function (10) estimation are presented in Table 1. The dependent variable is a $0-1$ variable that takes the value 1 if the unemployed individual indicated that $\mathrm{s} / \mathrm{he}$ searched for work by one of the identified search methods in the certain round of the survey and that this individual was subsequently employed in the next round, and zero otherwise. Note that during the time between the survey rounds an individual could have transitioned between employment and unemployment more than once. However, as Kiefer and Neumann (1979) pointed out, the reservation wages for each individual are assumed constant across time, as is the wage offer function, and it makes no difference what time frame is chosen ${ }^{13}$. The likelihood ratio statistic shows that the model is significantly different from the null or intercept only model by a $\chi^{2}$ test (346.3293 with 8 degrees of freedom). All variables, except number of children and number of elderly in the household, have an estimate significantly different from 0 , as

13 Keifer and Neumann (1979): p.178. 
judged by standard error, and further indicated by the column labeled $p>\chi^{2}$, which gives the upper bound of the probability of making a Type I error.

In the absence of "equal opportunity" legislation in Russia, sex is hypothesized to influence the probability of finding a job. It is not surprising to find that women are less likely to find a job than men, other things equal. The odds for women to be employed after looking for a job are estimated to be 0.775 times that of men, other things being equal. This result could be interpreted from two different perspectives. First, after the collapse of the Soviet system of equal employment for men and women, the employers (especially private firms) started to discriminate against women in mid-thirties and older, women with children (especially younger than school-age), and women with certain physical characteristics. Obviously, the majority of working age women fall into these categories, and thus the probability of their re-employment after being unemployed diminishes. However, a second explanation of the lesser odds for employment could lie in the fact that with labor market development and greater and higher paying opportunities resurfacing, women become choosier about jobs that they want to take, or they have an option of staying home. Both explanations appear intuitively plausible. The study of women's labor force participation, however, lies outside of the focus of this paper.

Experience is hypothesized to increase the likelihood of being re-employed ${ }^{14}$. In fact, however, each year of experience slightly reduces the probability of employment. Thus, other things equal, an additional year of experience would reduce the odds of reemployment after being unemployed by a factor of 0.973 . This might be the outcome of the increased demand on certain market skills that people with more work experience do not widely posses (e.g., computer literacy, market understanding, new work ethics, new management style, entrepreneurial ability, etc.). In fact, during the analyzed transition period younger people are much more employable than older people. ${ }^{15}$

\footnotetext{
${ }^{14}$ Some discussants of the earlier version of the paper suggested the inclusion of age as an explanatory variable. Experience and age are highly correlated in this data set (Pearson correlation coefficient is 0.84876 with $\mathrm{N}=11033$ ). Thus, we needed to choose one of the two characteristics. We considered experience to be more appropriate for the employment and wage functions analysis.

${ }_{15}$ The earlier analysis of the author revealed that respondents in the 21-30 years old cohort are much more successful in finding jobs than any other age cohort. In fact, on average, for this age group the odds of being employed are approximately 6 times higher than for people in their 60ties and older.
} 
The result for experience variable is quite intuitive and consistent with the labor economics literature. Since one would expect those with more employment experience to come at a higher price, companies might be reluctant to want to pay the premium when hiring them. By offering jobs to entry level workers, companies could train their employees specifically for their own company practices, rather than hiring someone who has a large amount of human capital which is at least partly specific to the previous firms that employed them. ${ }^{16}$

Education has a positive effect on the probability of employment, as would be expected. The odds for college graduates gaining employment after being unemployed are 1.673 times higher than for people who do not have a college degree, other things being equal.

Search effectiveness, or the probability of success in finding a job after using a particular search strategy, is hypothesized to increase the probability of re-employment. ${ }^{17}$ In fact, each percentage point increase in search effectiveness increases the odds of reemployment by a factor of 7.842, other things being equal. This is a very powerful result, which might be indicative of the fact that search strategies and their success rate are an important component of the labor market adjustment in Russia. The improvement of employment related programs and their success rate in placing people in jobs, development of new search methods (Internet search, for example), and increasing of the information data base in Russia would play an important role in decreasing the duration and level of unemployment.

We follow Holzer (1988) to measure search intensity as the number of search methods used rather than time spent. This decision rested on the data availability. Search intensity is hypothesized to increase the probability of successful job search. The model estimate shows that each unit increase in the number of methods used increases the odds of re-employment by the factor of 1.244 , other things equal. Unfortunately, $38 \%$ of people who searched through the identified channels only used one search method. A progressively smaller proportion of people used two methods (23\%), three methods (17\%), four methods (12\%), five methods (7\%) and six methods (3\%). (See Table A1.1.

\footnotetext{
${ }^{16}$ The experience variable discussion benefited from the comments of Laura Jean Bhadra, a discussant of the earlier version of this paper at the EEA 2003 Conference in New York, February 21, 2003.
} 
in Appendix 1.) The improvement of information infrastructure and establishment of job search training programs in Russia might speed up the movement of labor force from unemployment to employment.

The number of children in the family is hypothesized to influence the probability of employment. We estimated the effects of having children younger than age 7 (which is the start of schooling age in Russia) and in the age group of 7-18 in the household. As would be expected younger children decrease the probability of finding employment after being unemployed. Other things equal, each additional child of the age less than 7 years old would reduce the odds of re-employment after being unemployed by a factor of 0.920 . On the other hand, each additional child 7-18 years old increases the odds of reemployment by the factor of 1.055. These results are intuitive. Parents (and especially mothers) of young children would be less enthusiastic to obtain a job, would be less efficient in searching and hence have smaller probability of employment. When children start schooling, though, the parents are more compelled to find work because they have less justification for one parent staying home, and financial pressures increase.

This analysis does not address specific household composition factors: single parent or two-parents household; employment of both parents or of only one; male or female headed household; availability of caregivers (grandparents, babysitters, etc). These factors would clarify and enrich the understanding of the effect of number of children in the household on the employment choices of the family members. This extension lies outside of the scope of this paper.

The number of elderly in the household is another factor affecting re-employment probabilities. The elderly are males and females of post-working age. In Russia the postworking age for men is above 60 years old, and for women above 55 years old. The analysis takes into account this difference in retirement age. The existence of elderly in the household could influence the employment prospects of the younger generation positively (when grandparents are available for care-giving for young children and perform some home production duties) or negatively (when older people need special care themselves and thus preclude the younger generation from obtaining adequate employment, or contribute to financial and other household pressures, especially if they

${ }^{17}$ Methodology of calculating the search effectiveness vector is presented in Appendix 4. 
live in close quarters). Our estimate shows that, in the case of the Russian labor market, each additional person of post-working age decreases the odds of the younger generation to be re-employed by a factor of 0.895 , other things equal. This result seems intuitive, since meager pensions and unsatisfactory health care would call for additional responsibilities of the younger generation towards the elderly, which might prevent young people from being re-employed.

\subsection{Wage Offer Function for Russian Labor Market}

Table 2 presents the parameters of the wage offer function estimated by ordinary least squares. Two wage equations were considered. The standard wage equation is estimated over the sample of individuals who were unemployed in the previous round and employed in the subsequent round $(\mathrm{N}=967)$. In the wage equation corrected for selectivity bias the series on $\lambda$ constructed from the employment logit (11) was entered as a regressor in addition to the same explanatory variables as in the standard form. (In this specification $\mathrm{N}=824$ ). The dependent variable in both cases is the logarithm of nominal monthly wages.

As would be expected the strongest effect on the mean of wage offer distributions facing individuals in the local labor market is of private sector employment - the coefficients are 0.40 and 0.39 in standard and corrected models respectively.

Presumably, the wage offers are higher in private than in public sector, which would have an upward pressure on the wage offer function. It is reasonable to believe that the higher private sector employment will lead to higher mean wage offers. The level of public sector employment, on the other hand, has a negative effect on the wage the unemployed individual faces in the market in both models.

Education has an expected positive, significant and somewhat strong effect on wage offers in both models. Women, however, are significantly disadvantaged in the Russian labor market. In the absence of such policies as equal opportunity employment protections for women and support infrastructure for working mothers, it is not surprising to see that wage offers for women in the Russian labor market are much lower than those for men, other things equal. 
Years of experience has a negative and relatively small effect on the wage offers the individual subsequently receives. This can be interpreted as, holding previous earnings constant, an individual with greater job experience has more Soviet-stylespecific capital and less market-specific capital. Consequently, the wage offer function facing such individuals is lower because Soviet-style-specific capital is now worth less. ${ }^{18}$

The number of children at the pre-school age has a significant negative effect on the wage offer function in both specifications $((-0.16)$ and $(-0.12)$ respectively). The negative effect on wages is smaller for the number of older children (approximately (0.10 ) in both specifications). This makes sense since in Russia employees might discriminate against applicants with small children citing frequent absences due to children's sickness and other engagements. The time devoted to care for older children is presumably smaller, and thus the estimated smaller negative effect on wage offers in this case is plausible.

The number of elderly also has a significant negative effect on wage offers (around (-0.2) in both models). We can hypothesize that, in Russia, people who have elderly in the household would have settled for smaller wages because they are either in desperate need of any employment to support the extended family, or the pensions of the elderly supplement their household income, or they do not have childcare expenses since the elderly care for their children.

Search intensity estimates are positive, small but insignificant ( 0.03 and 0.04 in two models). Search intensity is measured by the number of methods used by the unemployed individual and thus hypothetically should increase the number of offers obtained and the level of accepted wage. However, the model assumes that only one offer is available for the applicant at any given point in time, and thus the forgone offer can not be recalled even if the present offer carries the smaller wage. It is interesting that the search intensity coefficients are the only insignificant estimates in these model specifications.

\footnotetext{
18 The negative effect of experience on the wage offer is intriguing, but ties this paper in with the literature on firm specific human capital. An interesting twist here, though, is that the human capital is not firm specific but rather system specific. Those employees that have accumulated a large amount of human capital specific to the Soviet style of doing things are now perceived by employers to be rigid in their accumulation of skills needed under the new market based way of doing business. (The experience
} 
Note that coefficients in the standard wage equation are slightly higher than the coefficients in the corrected wage equation for all variables except number of elderly and search intensity. That should be expected because $\lambda$ would capture some of the omitted variable effects in the later specification. The coefficient on $\lambda$ is substantial, positive but insignificant. The insignificance of $\lambda$ is consistent with Kiefer and Neumann (1979) and is desired. However, they obtained a small negative coefficient. From (4) and (6c) this coefficient is

$$
\left(\sigma_{0}^{2}-\sigma_{0, r}\right) /\left(\sigma_{0}^{2}-2 \sigma_{0, r}+\sigma_{r}^{2}\right)^{1 / 2},
$$

therefore $\sigma_{0, \mathrm{r}}<\sigma_{0}^{2}$ in our case. Thus, the error terms in the wage offer equation and the employment equation are positively correlated, and the error terms in the wage offer equation and the reservation wage equation are positively correlated. Kiefer and Neumann (1979) show that, under this specification, the estimate of the coefficient on $\lambda$ could be biased upward if any one of omitted variables affects market wages more than or the same as reservation wages, and biased downwards if one of the omitted variables has a greater effect on reservation wages.

In order to assess the goodness of fit of the corrected wage offer function we plotted the residual against its predicted values. The plot reveals a random scattering of points with no clear outliers, so we conclude that our wage offer model corrected for selectivity bias is adequate to characterize the data.

\section{Conclusions}

In this paper we estimated the employment and wage offer functions for the transforming labor market in Russia. The employment function showed that sex, experience, education, search effectiveness and search intensity play an important role in determining the probabilities of being re-employed. The best prospects for reemployment are for a college graduate male with fewer years of experience who used many different strategies when looking for a job.

The negative effects of the existence of small children and elderly in the household on re-employment probabilities demand the development of social services, 
which would create a high-quality, affordable, and universal child and elderly care in Russia. These government programs might increase the labor force participation rates and accelerate the transition to employment for unemployed individuals.

Search effectiveness is the most powerful factor among the ones we looked at. This leads us to the conclusion that improving the informational infrastructure and support services for unemployed, as well as training on the effective usage of job search strategies, might improve the speed of re-employment in Russia.

Private sector employment has the most powerful upward effect on the wage offer curve, followed by college education level. Public sector employment, being a female, number of years of experience, number of children, and number of elderly in the household, all have a negative affect on the wage offer distribution. We conclude that the development of policies promoting the growth of private sector, policies protecting women in the workplace and during the hiring process, and improvement of social services infrastructure in offering adequate child and elderly care, would increase the general level of wages faced by Russian unemployed and help build a stable environment in the Russian labor market.

It is interesting to note that the estimate of search intensity is not significant for wage offer function, but is significant for the probability of re-employment. The coefficients of number of children and number of elderly in the household are not significant for re-employment probabilities, but are significant for the wage offer function. This makes sense intuitively.

We applied for the first time Kieffer and Neumann's (1979), Narendranathan and Nickell's (1986), Holzer's (1988), and Hill's (1983) models to the Russian labor market data. All job search models assume a short time period during which the unemployed individual can not get more than one offer. The RLMS data has a year or even two years between survey rounds. Thus, any individual's search behavior might or might not be in violation of the main assumption of the models. Consequently, the search model results applied to this particular data set should be interpreted with caution.

Additionally, a central assumption used in estimating this model of search activity is that the wage offers are distributed log-normally. This assumption greatly facilitates the computation of estimates, since the conditional mean of a normal variable can be 
easily estimated. Alternative distributions could be considered, and their use would require full maximum likelihood estimation. It is beyond the scope of this paper to pursue this approach.

Furthermore, an analysis of the specific household composition factors (such as single parent or two-parents household; employment of both parents or of only one; male or female headed household; availability of caregivers (grandparents, babysitters, etc)) would clarify and enrich the understanding of the employment choices of the Russian families. Women's labor force participation decisions could also be considered in order to fully understand the labor market transformation. These are some interesting extensions of the analysis presented by this paper, and they might be the subjects of future research. 


\section{Table 1. Maximum Likelihood Logit Estimates of the Dichotomous Employment Function}

(Probability Modeled is Working=1)

\begin{tabular}{|c|c|c|c|c|c|c|}
\hline Independent Variable & Description & Estimate & St. Error & $x-S q$ & $p>x-S q$ & Odds Ratio \\
\hline Female & $=1$ if female; 0 if male & $-0.2548^{*}$ & -0.0722 & 12.469 & 0.0004 & 0.775 \\
\hline Years of Experience & continuous, range $=\{0,75\}$ & $-0.0258^{*}$ & 0.0028 & 88.0109 & $<0.0001$ & 0.975 \\
\hline College Graduate & $=1$ if college graduate; 0 if not & $0.5145^{*}$ & 0.1053 & 23.8709 & $<0.0001$ & 1.673 \\
\hline Search Effectiveness & $\begin{array}{l}\text { probability of employment } \\
\text { conditional on the search } \\
\text { strategy used (Table A2.1) }\end{array}$ & 2.0595 * & 0.4980 & 17.1036 & $<0.0001$ & 7.842 \\
\hline Number of Children $<7$ years old & $\begin{array}{l}\text { number of children younger } \\
\text { than } 7 \text { years old in the } \\
\text { household, range }=\{0,5\}\end{array}$ & -0.0838 & 0.0588 & 2.0309 & 0.1541 & 0.920 \\
\hline Number of Children $7-18$ years old & $\begin{array}{l}\text { number of children } 7-18 \text { years } \\
\text { old in the household, range }=\{0, \\
7\}\end{array}$ & 0.0534 & 0.0410 & 1.6971 & 0.1927 & 1.055 \\
\hline Number of Elderly & $\begin{array}{l}\text { number of post-work age males } \\
\text { and females in the household, } \\
\text { range }=\{0,3\}\end{array}$ & -0.1106 & 0.0759 & 2.1258 & 0.1448 & 0.895 \\
\hline Search Intensity & $\begin{array}{l}\text { Number of search methods } \\
\text { used when looking for a job, } \\
\text { range }=\{0,6\}\end{array}$ & 0.2181 * & 0.0287 & 57.8548 & $<0.0001$ & 1.244 \\
\hline Intercept & & $-1.2731^{*}$ & 0.1392 & 83.6732 & $<0.0001$ & \\
\hline $\begin{array}{l}\text { Likelihood Ratio X-Sq } \\
\text { DF } \\
\text { N }\end{array}$ & $\begin{array}{c}346.3293 \\
8 \\
4356\end{array}$ & & & & & \\
\hline
\end{tabular}

Note: * - significant at 5\% significance level. 
Table 2. Wage Offer Function

(OLS Estimates)

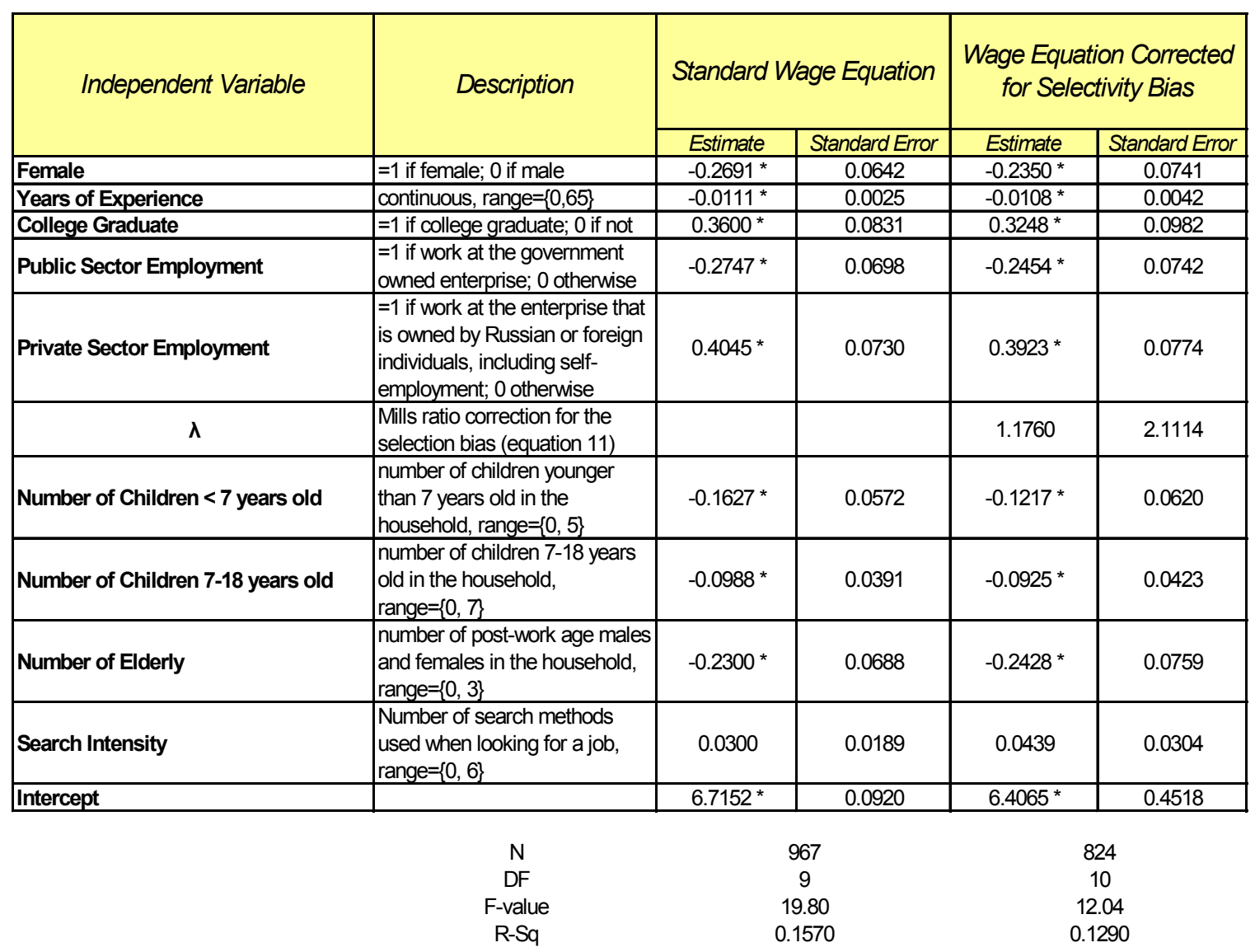

Note: * - significant at 5\% significance level. 


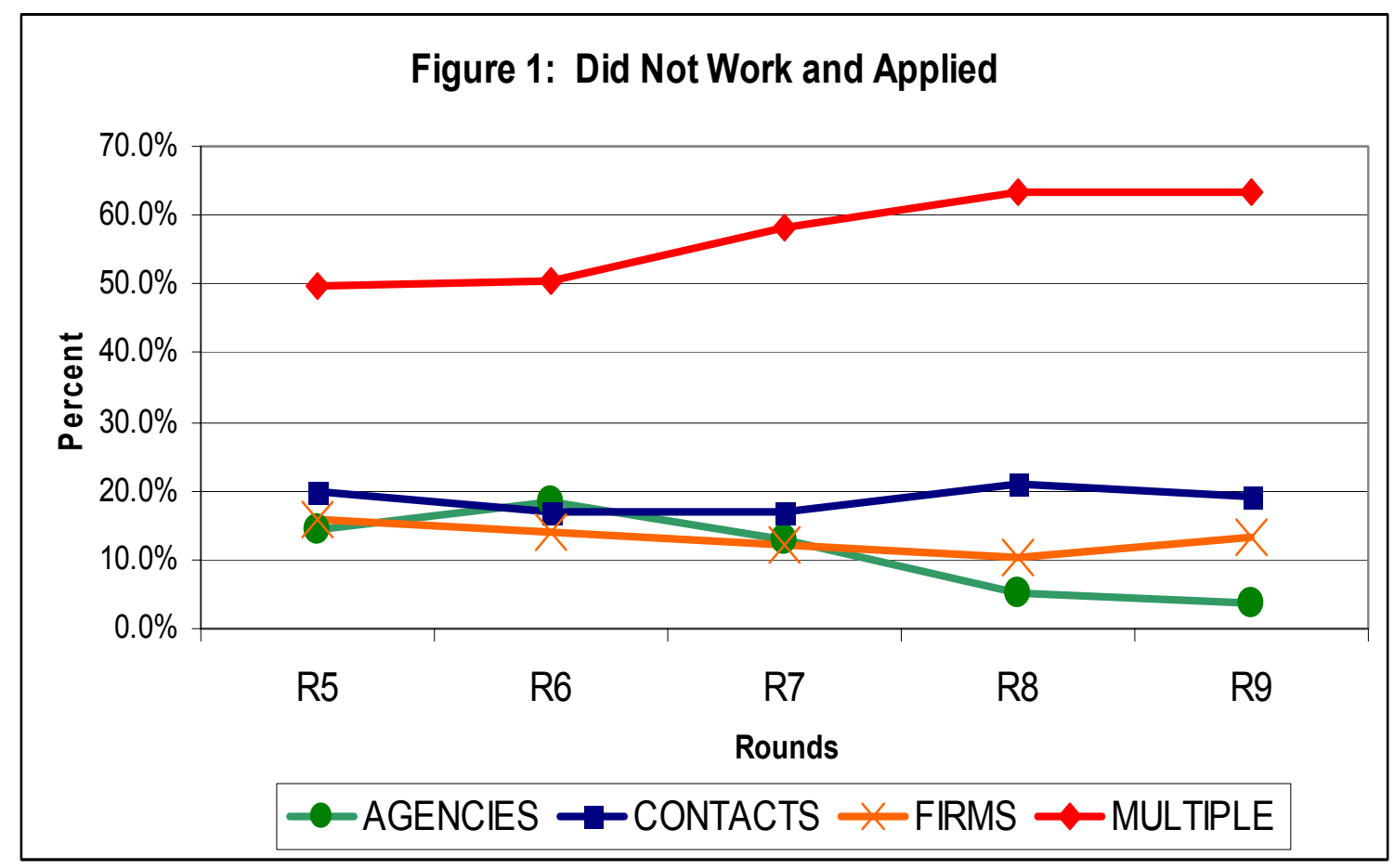




\section{Bibliography}

Aldrich, John H. and Nelson, Forrest D. 1984. Linear Probability, Logit, and Probit Models. Sage University Paper series on Quantitative Applications in the Social Sciences, 07-045. Newbury Park, CA: Sage.

Basu, Swati, Estrin, Saul, and Svejnar, Jan. 2000. Employment and Wages in Enterprises Under Communism and in Transition: Evidence From Central Europe and Russia. WDI Working paper No.440.

Bouev, Maxim. 2001. Labor Supply, Informal Economy and Russian Transition. WDI Working paper No.408.

Clarke, Simon. 1999. The Formation of a Labour Market in Russia. Edward Elgar, UK/USA.

Demaris, Alfred. 1992. Logit Modeling: Practical Applications. Sage University Paper series on Quantitative Applications in the Social Sciences, 07-086. Newbury Park, CA: Sage.

Devine, Theresa J. and Kiefer, Nicholas M. 1991. Empirical Labor Economics: The Search Approach. Oxford University Press, New York.

Foley, Mark C. 1997. Labor Market Dynamics in Russia. Yale University, Economic Growth Center Discussion Paper No.780.

Geishecker, Ingo; Haisken-DeNew, John P. 2002. Riding the Transitional RollerCoaster: Flexibility and the Inter-Industry Wage Structure in Russia. DIW Berlin, German Institute for Economic Research, Discussion Paper \# 280.

Gimpelson, Vladimir, and Lippoldt, Douglas. 2001. The Russian Labor Market: Between Transition and Turmoil. Rowman and Littlefield Publishers, USA.

Economics of Transition, 7(2): 505-533. . 1999. Private Sector Employment in Russia.

Glinskaya, Elena, and Mroz, Thomas A. 2000. The Gender Gap in Wages in Russia from 1992 to 1995. Journal of Population Economics, 13 (2), July 2000: 353-386.

Griffiths, William E., Hill, R. Carter, and Judge, George G. 1993. Learning and Practicing Econometrics. Willey \& Sons, USA.

Grogan, Louise; Van den Berg, Gerard. 1999. The Duration of Unemployment in Russia. CEPR Discussion Paper No.2268.

Hamermesh, Daniel S., and Rees, Albert. 1993. The Economics of Work and Pay. Fifth Edition. Harper Collins, New York. 
Hay, Joel Walker. 1980. Occupational Choice and Occupational Earnings: Selectivity Bias in a Simultaneous Logit-OLS Model. Unpublished Ph.D. Dissertation, Yale University.

Hill, M. Anne. 1983. Female Labor Force Participation in Developing and Developed Countries - Consideration of Informal Sector. The Review of Economics and Statistics: 459-468.

Heckman, J.J. 1979. Sample Selection Bias as a Specification Error. Econometrica, 47, January.

Holzer, Harry J. 1988. Search Method Use by Unemployed Youth. Journal of Labor Economics, 6(1): 1-20.

Kiefer, Nicholas M. 1988. Economic Duration Data and Hazard Functions. Journal of Economic Literature, Vol. XXVI (June 1988): pp.646-679.

Kiefer, Nicholas M. and Neumann, George R. 1979. Estimation of wage offer distributions and reservation wages. In: Studies in the Economics of Search. Lippman and McCall, eds. North-Holland, Amsterdam: pp.171-189.

Layard, Richard, Nickell, Stephen, Jackman, Richard. 1991. Unemployment: Macroeconomic Performance and the Labour Market. Oxford University Press.

Liao, Tim Futing. 1994. Interpreting Probability Models: Logit, Probit, and Other Generalized Linear Models. Sage University Paper series on Quantitative Applications on the Social Sciences, 07-101. Newbury Park, CA: Sage.

Linz, Susan J. 2002a. Motivating Russian Workers: Analysis of Age and Gender Differences. WDI Working Paper No.466.

\section{No.468.} 2002b. Job Satisfaction Among Russian Workers. WDI Working Paper

Mortensen, Dale T. 1999. New Developments in Models of Search in the Labor Market. In Handbook of Labor Economics, Vol. 3, Edited by O.Ashenfelter and D. Card, Ch.39, Elsevier Science Publishers BV: 2567-2627.

1986. Job Search and Labor Market Analysis. In Handbook of Labor Economics, Vol. II, Edited by O. Ashenfelter and R. Layard, Ch.15, Elsevier Science Publishers BV: 849-919.

Narendranathan, Wiji and Nickell, Stephen. 1986. Estimating the Parameters of Interest in a Job Search Model. In Blundell, Richard, and Walker, Ian. Unemployment, Search and Labor Supply. Cambridge University Press: 1-14.

Ogloblin, Constantin G. 1999. The Gender Earnings Differential in the Russian Transition Economy. Industrial and Labor Relations Review, 52(4), July 1999: 602-627. 
Stillman, Steven. 2001. Why Are Employment Rates So Low in Russia? RAND Labor and Population Program Working Paper.

. 2000a. The Determinants of Private and Government Sector Earnings in Russia. RAND Labor and Population Program Working Paper 00-17. . 2000b. Labor Market Uncertainty and Private Sector Labor Supply in Russia. WDI Working Paper No.359.

Van Ours, Jan. 2000. Do Active Labor Market Policies Help Unemployed Workers to Find and Keep Regular Jobs? IZA Working Paper No.121. 
$\underline{\text { Appendix } 1}$

Table A1.1. Sample Statistics for Pooled Data

\begin{tabular}{|c|c|c|c|}
\hline \multicolumn{2}{|l|}{ Variable } & Frequency & Percent \\
\hline \multirow[t]{2}{*}{ Sex } & $\begin{array}{l}\text { Female } \\
\text { Male }\end{array}$ & $\begin{array}{l}8429 \\
4857\end{array}$ & $\begin{array}{l}64.0 \\
36.0\end{array}$ \\
\hline & Total & 13286 & 100 \\
\hline \multirow[t]{2}{*}{ Education } & \begin{tabular}{|l|} 
College Graduate \\
Not College Graduate
\end{tabular} & \begin{tabular}{c|}
1179 \\
12107
\end{tabular} & $\begin{array}{c}8.9 \\
91.1\end{array}$ \\
\hline & \begin{tabular}{|ll} 
& Total \\
\end{tabular} & 13286 & 100 \\
\hline \multirow[t]{2}{*}{ Experience } & \begin{tabular}{|l|}
$0-10$ years \\
$11-20$ years \\
$21-30$ years \\
$31-40$ years \\
$41+$ years
\end{tabular} & $\begin{array}{l}2488 \\
1242 \\
1609 \\
3290 \\
2404 \\
\end{array}$ & $\begin{array}{l}22.6 \\
11.3 \\
14.6 \\
29.8 \\
21.8\end{array}$ \\
\hline & Total & 11033 & 100 \\
\hline \multirow[t]{2}{*}{ Sector } & $\begin{array}{l}\text { Public } \\
\text { Private }\end{array}$ & $\begin{array}{l}938 \\
558\end{array}$ & $\begin{array}{l}63.0 \\
37.0\end{array}$ \\
\hline & Total & 1496 & 100 \\
\hline \multirow[t]{2}{*}{$\begin{array}{l}\text { Number of children smaller than } 7 \text { years old } \\
\text { in household }\end{array}$} & $\begin{array}{l}0 \\
1 \\
2 \\
3 \\
4 \\
5 \\
\end{array}$ & $\begin{array}{c}10608 \\
1928 \\
415 \\
85 \\
24 \\
7 \\
\end{array}$ & $\begin{array}{c}81.2 \\
14.8 \\
3.2 \\
0.7 \\
0.2 \\
0.1 \\
\end{array}$ \\
\hline & Total & 13067 & 100 \\
\hline \multirow[t]{2}{*}{$\begin{array}{l}\text { Number of children 7-18 years old } \\
\text { in household }\end{array}$} & $\begin{array}{l}0 \\
1 \\
2 \\
3 \\
4 \\
5 \\
6 \\
7\end{array}$ & $\begin{array}{c}8494 \\
2777 \\
1465 \\
228 \\
68 \\
15 \\
10 \\
10\end{array}$ & $\begin{array}{c}65.0 \\
21.3 \\
11.2 \\
1.7 \\
0.5 \\
0.1 \\
0.1 \\
0.1\end{array}$ \\
\hline & Total & 13067 & 100 \\
\hline \multirow[t]{2}{*}{ Number of elderly in household } & $\begin{array}{l}0 \\
1 \\
2 \\
3 \\
\end{array}$ & \begin{tabular}{c|}
6231 \\
6404 \\
423 \\
9 \\
\end{tabular} & $\begin{array}{l}47.7 \\
49.0 \\
3.2 \\
0.1 \\
\end{array}$ \\
\hline & Total & 13067 & 100 \\
\hline \multirow[t]{2}{*}{ Employment Status } & $\begin{array}{l}\text { Working } \\
\text { Not Working }\end{array}$ & $\begin{array}{c}1659 \\
11627\end{array}$ & $\begin{array}{l}12.3 \\
87.7\end{array}$ \\
\hline & Total & 13286 & 100 \\
\hline From those who work & \begin{tabular}{|l|} 
Female \\
Male \\
College Graduate \\
Public Sector \\
Private Sector
\end{tabular} & $\begin{array}{l}872 \\
787 \\
255 \\
885 \\
527 \\
\end{array}$ & $\begin{array}{l}52.6 \\
47.4 \\
15.4 \\
53.3 \\
31.8\end{array}$ \\
\hline \multirow[t]{2}{*}{$\begin{array}{l}\text { From those who do not work } \\
\text { and answered the question }\end{array}$} & $\begin{array}{l}\text { Did not Apply for Work } \\
\text { Applied for Work }\end{array}$ & $\begin{array}{l}3195 \\
1610 \\
\end{array}$ & $\begin{array}{l}66.5 \\
33.5\end{array}$ \\
\hline & Total & 4805 & 100 \\
\hline \multirow[t]{2}{*}{ From those who applied for work } & $\begin{array}{l}\text { Used the following methods } \\
\text { Agencies } \\
\text { Contacts } \\
\text { Firms } \\
\text { Multiple }\end{array}$ & $\begin{array}{l}218 \\
355 \\
271 \\
766 \\
\end{array}$ & $\begin{array}{l}13.5 \\
22.0 \\
16.8 \\
47.6 \\
\end{array}$ \\
\hline & Total & 1610 & 100 \\
\hline \multirow[t]{2}{*}{ Number of Search Methods Used } & $\begin{array}{l}0 \\
1 \\
2 \\
3 \\
4 \\
5 \\
6\end{array}$ & $\begin{array}{c}11427 \\
705 \\
433 \\
315 \\
230 \\
127 \\
49\end{array}$ & $\begin{array}{c}86.0 \\
5.3 \\
3.3 \\
2.4 \\
1.7 \\
1.0 \\
0.4\end{array}$ \\
\hline & Total & 13286 & 100.0 \\
\hline
\end{tabular}

Note: The totals are not equal due to missing observations. 
$\underline{\text { Appendix } 2}$

\section{Methodology for Correction of Wage Equation for Sample Selection Bias}

We follow Hill's (1983) method of correction for selectivity bias in the multinomial logit model. The inverse Mill's ratio $(\lambda)$ in this case takes the following form $^{19}$ :

$$
\left.\lambda_{\mathrm{ji}}=\left(6 / \pi^{2}\right)(-1)^{\mathrm{J}+1}\left[\Sigma_{\mathrm{k} \neq \mathrm{j}}(1 / \mathrm{J})\left(\mathrm{P}_{\mathrm{ki}} / 1-\mathrm{P}_{\mathrm{ki}}\right) \log \left(\mathrm{P}_{\mathrm{ki}}\right)+((\mathrm{J}-1) / \mathrm{J})\right) \log \left(\mathrm{P}_{\mathrm{ji}}\right)\right]
$$

where $\mathrm{J}$ is the total number of alternatives and $\mathrm{P}_{\mathrm{ji}}$ is the selection probability for the $j^{\text {th }}$ alternative.

The method for estimating wage equations free from sample selection bias is to estimate the reduced form employment function (10), to use the estimated parameters to calculate each $P_{\mathrm{ji}}$, then to calculate $\lambda_{\mathrm{ji}}(\mathrm{A} 2.1)$ based on these values, and to include these $\lambda_{\mathrm{ji}}$ as regressors in the wage equation (9).

${ }^{19}$ Hill (1983), p.467. 
Table A3.1. Variables Used in the Analysis

$\underline{\text { Appendix } 3}$

\begin{tabular}{|c|c|c|c|c|}
\hline Variable & Description & $N$ & Mean & St.Dev. \\
\hline Female & $=1$ if female; 0 if male & 13286 & 0.6344 & 0.4816 \\
\hline Years of Experience & continuous, range $=\{0,75\}$ & 11033 & 27.2343 & 16.1323 \\
\hline College Graduate & $=1$ if college graduate; 0 if not & 13286 & 0.0887 & 0.2844 \\
\hline Public Sector Employment & $\begin{array}{l}=1 \text { if work at the government } \\
\text { owned enterprise; } 0 \text { otherwise }\end{array}$ & 13286 & 0.0706 & 0.2562 \\
\hline Private Sector Employment & $\begin{array}{l}=1 \text { if work at the enterprise that } \\
\text { is owned by Russian or foreign } \\
\text { individuals, including self- } \\
\text { employment; } 0 \text { otherwise }\end{array}$ & 13286 & 0.0420 & 0.2006 \\
\hline Working & $\begin{array}{l}=1 \text { if works at the time of the } \\
\text { interview; } 0 \text { otherwise }\end{array}$ & 13286 & 0.1249 & 0.3306 \\
\hline Wages & $\begin{array}{l}\text { amount of wages at primary } \\
\text { job in the month prior to the } \\
\text { interview month }\end{array}$ & 1161 & 929.5267 & 1199.0100 \\
\hline Number of Children $<7$ years old & $\begin{array}{l}\text { number of children younger } \\
\text { than } 7 \text { years old in the } \\
\text { household, range }=\{0,5\}\end{array}$ & 13067 & 0.2406 & 0.5640 \\
\hline Number of Children 7-18 years old & $\begin{array}{l}\text { number of children } 7-18 \text { years } \\
\text { old in the household, range }=\{0, \\
7\}\end{array}$ & 13067 & 0.5256 & 0.8478 \\
\hline Number of Elderly & $\begin{array}{l}\text { number of post-work age } \\
\text { males and females in the } \\
\text { household, range }=\{0,3\}\end{array}$ & 13067 & 0.5569 & 0.5618 \\
\hline Search Intensity & $\begin{array}{l}\text { Number of search methods } \\
\text { used when looking for a job, } \\
\text { range }=\{0,6\}\end{array}$ & 13286 & 0.3285 & 0.9683 \\
\hline
\end{tabular}




\section{Appendix 4}

Table A4.1. Effectiveness of Job Search Strategies (Binomial Logit Estimation)

\begin{tabular}{|l|c|}
\hline \multicolumn{1}{|c|}{ Strategies } & $\begin{array}{c}\text { Predicted Probabilities } \\
\text { of Employment After } \\
\text { Using Search Strategy }\end{array}$ \\
\hline AGENCY & $26.1 \%$ \\
\hline CONTACTS & $31.5 \%$ \\
\hline FIRMS & $29.2 \%$ \\
\hline MULTIPLE & $42.4 \%$ \\
\hline NOT APPLIED & $19.5 \%$ \\
\hline
\end{tabular}

$\quad N$
-2 Log L
X-Sq
DF

5581

6173.104

185.3768

4

Note: the predicted probabilities are calculated using the binomial logit function of the form:

$$
\ln \left[\begin{array}{l}
\operatorname{Prob}\left(\text { working }_{t+1}=1\right) \\
\hline \operatorname{Prob}\left(\text { working }_{t+1}=0\right)
\end{array}\right]=\sum_{k=1}{ }^{K} \beta_{k} x_{k}
$$

where $\operatorname{Prob}\left(\right.$ working $\left._{t+1}=1\right)=\left[\exp \left(\sum_{k=1}{ }^{K} \beta_{k} x_{k}\right)\right] /\left[1+\exp \left(\sum_{k=1}^{K} \beta_{k} x_{k}\right)\right]$, and $x_{k=5}$ represents a vector of job search strategies. 


\section{DAVIDSON INSTITUTE WORKING PAPER SERIES - Most Recent Papers}

The entire Working Paper Series may be downloaded free of charge at: www.wdi.bus.umich.edu

CURRENT AS OF 2/21/03

\begin{tabular}{|c|c|c|}
\hline Publication & Authors & Date \\
\hline $\begin{array}{l}\text { No. 547: Re-employment Probabilities and Wage Offer Function for } \\
\text { Russian Labor Market }\end{array}$ & Natalia V. Smirnova & Feb. 2003 \\
\hline $\begin{array}{l}\text { No. 546: Democratization's Risk Premium: Partisan and Opportunistic } \\
\text { Political Business Cycle Effects on Sovereign Ratings in Developing } \\
\text { Countries }\end{array}$ & $\begin{array}{l}\text { Steven Block, Burkhard N. } \\
\text { Schrage and Paul M. Vaaler }\end{array}$ & Feb. 2003 \\
\hline $\begin{array}{l}\text { No. 545: Structural Reforms and Competitiveness: Will Europe } \\
\text { Overtake America? }\end{array}$ & Jan Svejnar & Feb. 2003 \\
\hline No. 544: Why the Rich May Favor Poor Protection of Property Rights & Konstantin Sonin & Dec. 2002 \\
\hline $\begin{array}{l}\text { No. 543: Reinvested Earnings Bias, The "Five Percent" Rule and the } \\
\text { Interpretation of the Balance of Payments - With an Application to } \\
\text { Transition Economies }\end{array}$ & $\begin{array}{l}\text { Josef C. Brada and Vladimír } \\
\text { Tomšík }\end{array}$ & Feb. 2003 \\
\hline $\begin{array}{l}\text { No. 542: The Impact of Ownership Reform in Chinese Industry, 1995- } \\
2001\end{array}$ & $\begin{array}{l}\text { Gary H. Jefferson, Su Jian, Jiang } \\
\text { Yuan and Yu Xinhua }\end{array}$ & Feb. 2003 \\
\hline $\begin{array}{l}\text { No. 541: Defensive and Strategic Restructuring of Firms during the } \\
\text { Transition to a Market Economy }\end{array}$ & $\begin{array}{l}\text { Domadenik, Janez Prašnikar and } \\
\text { Jan Svejnar }\end{array}$ & Feb. 2003 \\
\hline No. 540: Tenuous Financial Stability & $\begin{array}{l}\text { Neven T. Valev and John A. } \\
\text { Carlson }\end{array}$ & Feb. 2003 \\
\hline $\begin{array}{l}\text { No. 539: Non-monetary Trade and Differential Access to Credit in the } \\
\text { Russian Transition }\end{array}$ & Vlad Ivanenko & Feb. 2003 \\
\hline $\begin{array}{l}\text { No. 538: International Price-Fixing Cartels and Developing Countries: } \\
\text { A Discussion of Effects and Policy Remedies }\end{array}$ & $\begin{array}{l}\text { Margaret Levenstein and Valerie } \\
\text { Suslow with Lynda Oswald }\end{array}$ & Feb. 2003 \\
\hline No. 537: Foreign Banks in Bulgaria, 1875-2002 & $\begin{array}{l}\text { Kenneth Koford and Adrian E. } \\
\text { Tschoegl }\end{array}$ & Jan. 2003 \\
\hline $\begin{array}{l}\text { No. 536: Forthcoming in Vanderbilt Journal of Transnational Law, } \\
\text { "Healthy Organizations and the Link to Peaceful Societies: Strategies } \\
\text { for Implementing Organizational Change" }\end{array}$ & $\begin{array}{l}\text { Jeannette Jackson and Maria } \\
\text { Coolican }\end{array}$ & Jan. 2003 \\
\hline $\begin{array}{l}\text { No. 535: Forthcoming in Vanderbilt Journal of Transnational Law, } \\
\text { "Workplace Violence and Security: Are there Lessons for } \\
\text { Peacemaking?" }\end{array}$ & $\begin{array}{l}\text { Frances E. Zollers and Elletta } \\
\text { Sangrey Callahan }\end{array}$ & Jan. 2003 \\
\hline $\begin{array}{l}\text { No. 534: Forthcoming in Vanderbilt Journal of Transnational Law, } \\
\text { "700 Families to Feed: The Challenge of Corporate Citizenship" }\end{array}$ & Tara J. Radin & Jan. 2003 \\
\hline $\begin{array}{l}\text { No. 533: Forthcoming in Vanderbilt Journal of Transnational Law, } \\
\text { "Governing for Genuine Profit" }\end{array}$ & Michael J. O'Hara & Jan. 2003 \\
\hline $\begin{array}{l}\text { No. 532: Forthcoming in Vanderbilt Journal of Transnational Law, } \\
\text { "Adapting Corporate Governance for Sustainable Peace" }\end{array}$ & $\begin{array}{l}\text { Timothy L. Fort and Cindy A. } \\
\text { Schipani }\end{array}$ & Jan. 2003 \\
\hline $\begin{array}{l}\text { No. 531: Forthcoming in Vanderbilt Journal of Transnational Law, } \\
\text { "Groundings of Voice in Employee Rights" }\end{array}$ & Dana Muir & Jan. 2003 \\
\hline $\begin{array}{l}\text { No. 530: Forthcoming in Vanderbilt Journal of Transnational Law, } \\
\text { Gender Voice and Correlations with Peace }\end{array}$ & $\begin{array}{l}\text { Morehead Dworkin and Cindy A. } \\
\text { Schipani }\end{array}$ & Jan. 2003 \\
\hline $\begin{array}{l}\text { No. 529: Forthcoming in Vanderbilt Journal of Transnational Law, } \\
\text { "The Organizational Model for Workplace Security" }\end{array}$ & Dr. Thomas K. Capozzoli & Jan. 2003 \\
\hline $\begin{array}{l}\text { No. 528: Forthcoming in Vanderbilt Journal of Transnational Law, } \\
\text { "Nationbuilding 101: Reductionism in Property, Liberty, and Corporate } \\
\text { Governance" }\end{array}$ & O. Lee Reed & Jan. 2003 \\
\hline $\begin{array}{l}\text { No. 527: Forthcoming in Vanderbilt Journal of Transnational Law, "On } \\
\text { Virtue and Peace: Creating a Workplace Where People Can Flourish" }\end{array}$ & $\begin{array}{l}\text { Caryn L. Beck-Dudley and } \\
\text { Steven H. Hanks }\end{array}$ & Jan. 2003 \\
\hline $\begin{array}{l}\text { No. 526: Forthcoming in Vanderbilt Journal of Transnational Law, } \\
\text { "Novartis and the United Nations Global Compact Initiative" }\end{array}$ & Lee A. Tavis & Dec. 2002 \\
\hline $\begin{array}{l}\text { No. 525: Why Transition Paths Differ: Russian and Chinese Enterprise } \\
\text { Performance Compared }\end{array}$ & Sumon Bhaumik and Saul Estrin & Jan. 2003 \\
\hline $\begin{array}{l}\text { No. 524: Official Regulations and the Shadow Economy: A Labour } \\
\text { Market Approach }\end{array}$ & Maxim Bouev & Dec. 2002 \\
\hline No. 523: Children at Risk: Infant and Child Health in Central Asia & Cynthia Buckley & Jan. 2003 \\
\hline
\end{tabular}

